\section{Sulphonylurea and insulin: combined treatment in Type 1 (insulin-dependent) diabetes}

Dear Sir,

In contrast to the recent observations of Ratzmann et al. [1] that tolbutamide is not a useful adjunct to insulin treatment in Type 1 diabetes, I would like to refer to our recent work on a similar theme [2]. We demonstrated that when a combination of insulin and glibenclamide treatment was given to patients with Type 1 diabetes in a randomized and double-blind cross-over trial for periods of 3 months, measurements of diabetic control improved significantly in those patients who retained residual endogenous insulin secretion. During an oral glucose tolerance test 3 months after combined treatment, C-peptide secretion increased by $47 \%$, the mean \pm SD daily blood glucose level fell from $8.4 \pm 1.7$ to $7.4 \pm 1.5 \mathrm{mmol} / 1(p<0.02)$ and the mean glycosylated haemoglobin decreased from $8.1 \pm 0.5 \%$ to $7.5 \pm 0.9 \%$ $(p<0.05)$. These results substantiate a previous study [3] which showed that glibenclamide, when added to the insulin regimen of Type 1 diabetic patients with residual insulin secretion, increased their C-peptide secretion by $60 \%$ over a 1 -month period.

Less than half of the seven subjects in Ratzmann et al.'s study could be described as having retained residual endogenous insulin secretion according to the criteria of Madsbad [4] of a plasma C-peptide concentration $>0.07 \mathrm{mmol} / \mathrm{l}$. Although limited insulin and glibenclamide treatment may be only of limited value, 1 believe that further research is needed to follow up our observations and determine how long increased insulin secretion and improved metabolic control persist.

Yours sincerely,

B.J. Burke

\section{References}

1. Ratzmann KP, Schulz B, Heinke P, Besch W (1984) Tolbutamide does not alter insulin requirement in Type 1 (insulin-dependent) diabetes. Diabetologia 27: 8-12

2. Burke BJ, Hartog M, Waterfield MR (1984) Improved diabetic control in insulin-dependent diabetics treated with insulin and glibenclamide. Acta Endocrinol 107: 70-77

3. Burke BJ, Sherrif RJ (1980) Stimulation of residual insulin secretion by glibenclamide in insulin-dependent diabetics. Acta Endocrinol 95: $372-375$

4. Madsbad S (1983) Prevalence of residual B-cell function and its metabolic consequences in Type 1 (insulin-dependent) diabetes. Diabetologia 24: 141-147

Dr. B.J. Burke

Edgware General Hospital

Edgware

Middlesex HA8 OAD

UK

\section{Reply from the authors}

\section{Dear Sir}

Burke et al. [1] demonstrated that combined insulin and glibenclamide treatment for 3 months may produce useful improvement of diabetic control in Type 1 (insulin-dependent) diabetic patients who retained residual endogenous insulin secretion. In contrast to this observation, Ward et al. [2] failed to demonstrate any additive effect of sulphonylurea treatment in addition to insulin on the control of blood glucose in Type 1 diabetes. In addition, Burke and Sherrif [3] showed no beneficial effect on metabolic control in Type 1 diabetic patients after 4 weeks' treatment with glibenclamide and insulin, although a significant increase in residual $\beta$-cell function was demonstrated.
The mechanism by which sulphonylureas lower blood glucose appears to result from the release of insulin and, possibly, also by extrapancreatic mechanisms. We examined whether tolbutamide has any acute or short-term effects on insulin action in Type 1 diabetes [4]. The results suggest that tolbutamide does not exert any acute or short-term effects on insulin action in vivo. Our results do not provide support for the idea that this agent is a clinically useful adjunct to insulin in such patients. The failure to demonstrate any extra-pancreatic effects of tolbutamide in Type 1 diabetic patients is in agreement with data on forearm insulin-mediated glucose uptake in non-diabetic and diabetic subjects $[5,6]$. Grunberger et al. [7] demonstrated similar results. In our study, treatment with tolbutamide, in addition to insulin, for 6 days failed to increase fasting C-peptide levels in three patients with residual endogenous insulin secretion [4]. A variety of factors, including the type of sulphonylurea, the dose and duration of therapy, could explain the differences between the results of our study [4] and the clinical report on a randomized double-blind with glibenclamide for 3 months [1]. I agree with the view of Dr. Burke that further research is necessary to follow up his observations and to determine how long increased insulin secretion and improved metabolic control persist.

Yours sincerely,

K.P. Ratzmann

\section{References}

1. Burke BJ, Hartog M, Waterfield MR (1984) Improved diabetic control in insulin-dependent diabetics treated with insulin and glibenclamide. Acta Endocrinol 107: 70-77

2. Ward EA, Ward GM, Turner RC (1981) Effect of sulphonylurea on insulin secretion and glucose control in insulin-treated diabetics. $\mathrm{Br}$ Med J 283: 278-281

3. Burke BJ, Sherrif RJ (1980) Stimulation of residual insulin secretion by glibenclamide in insulin-dependent diabetics. Acta Endocrinol 95: $372-375$

4. Ratzmann KP, Schulz B, Heinke P, Besch W (1984) Tolbutamide does not alter insulin requirement in Type 1 (insulin-dependent) diabetes. Diabetologia $27: 8-12$

5. Butterfield WJH, Arab MMH, Buckle ALJ, Chlouverakis C, Hanley T, Mahler RF, Whichelow MJ (1962) The mechanisms of action of tolbutamide. Observations on the effects of sulfonylureas on peripheral metabolism in man. Diabetes 11: 43-49

6. Zinman B, Ogilvie RJ (1972) The acute effects of tolbutamide on forearm metabolism. J Clin Endocrinol Metab 35: 299-306

7. Grunberger G, Ryan J, Gorden PH (1982) Sulphonylureas do not affect insulin binding or glycemic control in insulin-dependent diabetic. Diabetes 31: 890-896

Dr. Klaus P. Ratzmann

Centre for Diabetes and Metabolic Disorders

Klosterstraße 71-72

DDR-1020 Berlin

GDR

\section{Continuing high incidence of diabetes mellitus in Scottish children}

Dear Sir,

We reported recently a substantial rise in the incidence of diabetes mellitus in childhood for the years 1968-76 in Scotland [1]. We have continued to monitor admissions to Scottish hospitals of children aged less than 19 years and can now report the estimated incidence rates for the years 1977 to 1979 . Table 1 shows first admission incidence rates for the years 1968 to 1979 . Rates for the years up to 1976 have been corrected for readmissions as previously described [1]. 